\title{
咬みしめ時の茵列における咬合力分布
}

\author{
服部佳功, 佐藤智昭, 渡辺 誠 \\ 東北大学歯学部高齢者歯科学講座（主任：渡辺誠教授） \\ 〔受付：平成 7 年10月12日〕
}

\section{Bite force distribution on dental arch during clenching}

\author{
Yoshinori Hattori, Chiaki Satoh and Makoto Watanabe \\ Department of Geriatric Dentistry, Tohoku University School of Dentistry \\ (Director: Prof. Makoto Watanabe) \\ [Recieved: October 12, 1995.]
}

Key Words: bite force, bite force distribution, pressure sensitive film

\begin{abstract}
This study aimed to clarify the normal pattern of bite force distribution on the dental arch during maximum voluntary clenching at intercuspal position. Bite force was measured in forty two normal dentate subjects using pressure sensitive film, "Dental Prescale 50H, type R" (Fuji Photo Film, Co.). Bite force distribution was expressed as a percentage of bite force on each tooth to the total force. The symmetry of bite force distribution was investigated using asymmetry index, which was defined as a percentage of the difference between the right and left side bite forces to the sum (IR-LI/(R+L)x100 [\%]). Measured bite force ranged from 205 to 1,963 N (mean \pm S.D.: $879 \pm 388$ $\mathrm{N})$. The distribution of bite force was characterized by posteriorly increasing forces, and the force reached to the peak at the second molar irrespective of the presence of the third molar occlusal contacts. However, the bite force distribution on anterior teeth was smaller in the subjects with contacts at the third molar than in the subjects without contacts. Mean asymmetry index of the bite force distribution was $9.3 \pm 6.7 \%$ in all subjects, that showed symmetrical distribution of bite force. Asymmetry index was smaller in the subjects with contacts in the third molars than in the subjects without contact. The patterns of bite force on dental arches, presented in this study, are useful for the clinical application of bite force measurement in occlusal diagnosis.
\end{abstract}

抄録 歯列における咬合力分布の正常像を得る目的で，顎口腔系に機能異常とその既往を有さない有歯顎 者42名の被験者より，咬みしめ時の咬合力を記録した。被験者には「できるだけ強く」咬みしめるよう指 示した. 咬合力記録には, 咬合力測定用感圧フィルムDental Prescale 50H, type Rと専用の解析装置Dental Occlusion Pressuregraph, Occluzer, FPD-703（ともに富士写真フィルム社製）を用いた。各歯の咬合力の 総咬合力に対する比（咬合力比）ならびに左右各側歯列における咬合力の差が総咬合力に占める比（非対 称性指数）を求め，咬合力分布の分析に供した.

片側歯列について各歯の咬合力比を比較したところ，第 2 大臼歯で最大值を示し，おおむね後方歯から 前方歯にかけて順に減少した。第 3 大臼歯に咬合接触を有する群では, その咬合力比は第 2 大臼歯より小 さく第 1 大臼歯より大きかった。この咬合力の前後的分布は, 各歯の咬合力の負担能力, 咀嚼筋活動, 槓

連絡先：干980-77 仙台市青葉区星陵町 4-1 
桿作用，顎口腔系の変形などの統合の結果もたらされたものと推察された.

一方，咬合力の非対称性指数は平均 $9.3 \pm 6.7 \% て ゙ ，$ 正常機能を営む顎口腔の力学的特徵である，咬合力 の左右的に均等な分布が認められた。また，咬合接触を有する第 3 大臼歯数別に非対称性指数を比較した ところ，その数が多い順に非対称性は小さく，咬合接触を有する臼歯数の増大に伴う咬合力分布の左右的 均等化が示唆された。

本研究において明らかにされた咬合力分布の正常像は，咬合力分布の測定を咬合診査に応用する際に， 基準としうるものであり，その臨床的有用性が推察された。

\section{I. 緒 言}

咬みしめ時に咀嚼筋群の発揮する収縮力は，おもに歯 列と顎関節により負担される。歯列上の各咬合接触点お よび両側顎関節に作用する力の大きさや方向は，咀嚼筋 の活動様式，下顎位，上下顎歯の咬合，顎骨や歯周組織 の物理的性質などと密接に関連すると考えられる．換言 すれば，咬みしめ時の咬合力分布，すなわち歯列に作用 する咬合力の各歯における配分は，顎口腔系の形態や機 能を直接に反映する．したがって，咬合力分布の正常像 を明らかにすることは，顎機能の理解と咬合診断に，き わめて意義深いと考えられる。

これまで，歯列上の多点に咬みしめ時に作用する咬合 力を，同時かつ定量的に記録することは，必ずしも容易 ではなかった。しかしながら，感圧測定範囲を可及的に 拡大したあたらしい咬合力測定材料 Dental Prescale 50H （富士写真フィルム株式会社）が開発され，正常有歯顎 者の最大咬みしめ時における咬合力の測定が可能となっ た ${ }^{1}$ 。本材料を用いて測定された咬合力は，最大咬みし め時において下顎歯列上で前方歯から後方歯にかけて増 大し，咬合力の大きさは左右側でほほ同量であった。

一方，咬みしめ強さが咬合力分布に及ぼす影響を検索 した結果，中等度以上の咬みしめにおいては同一被験者 の咬合力分布はほぼ一定であり，被験者間ではそれぞれ 異なることが明らかになった，以上の知見より，中等度 以上の咬みしめを行う際の咬合力分布が，各人に固有で あることが判明した ${ }^{21}$

そこで本研究では，正常な顎口腔機能を営む若年の成 人を対象に，咬合力とその歯列における分布を測定し， 正常有歯顎者における平均的分布像を明らかにすること を試みた。

\section{II. 方 法}

\section{1. 被験者}

本学歯学部 2 年次に在籍する学生 57 名より, 診査のの ち顎口腔系に機能異常とその既往を認めなかった 42 名 （男性36名，女性 6 名）を抽出し，被験者とした。各被 験者には，本研究の目的ならびに方法に関する説明を行 い, 同意を得た。

\section{2. 咬合力測定方法}

咬合力測定には, 咬合力測定用感圧フィルム Dental Prescale $50 \mathrm{H}$ ，type R，拉よび尃用の解析装置 Dental Occlusion Pressuregraph, Occluzer, FPD-703 (ともに富 士写真フィルム株式会社製）を用いた。本感圧フィルム は厚さが $97 \mu \mathrm{m} て ゙ ， 5 \sim 120 \mathrm{MPa}$ 感圧測定範囲を有す る.

\section{3. 咬合力測定ならびに分析方法}

測定にさきだち，各被験者の口腔内診査を行い，シリ コーン印象材（株式会社ジーシー製, Flexicon, injection type）を用いてチェックバイトを記録した.

被験者に，背もたれのない椅子上で，頭位を直立位と する座位をとらせた１横歯程度開口させ，上下顎歯列 間に感圧フィルムを挿入し，ゆっくりと閉口させ，つい で「できるかぎり強く」咬みしめるよう指示した，咬み しめの持続時間は 1 秒間とした。また，咬みしめ強さは 各被験者の随意によるものとし，咬みしめ強さを規定す る手段を用いなかった，各被験者における記録の回数は 1 回とし, フィルム定位の誤りなど, 明らかな失敗の場 合のみ, 再度の記録を行った。

記録の 3 時間後に，解析装置により，下顎の各歯につ いて，咬合力の測定を行った．感圧フィルム上の発色し た赤色部位をさきに記録したチェックバイトと照合し， 位置と形態から咬合力の作用部位を同定した。発色があ りながら，チェックバイトに対応する咬合接触部位のな い部位は，フィルムの折れ曲がりなどによるアーチファ クトとみなして，測定の対象外とした。

分析は，測定された下顎各歯に扔ける咬合力を基に， 
表 1 各歯における平均咬合力

Table 1 Mean bite force on each tooth

\begin{tabular}{cccrc}
\hline \hline \multirow{2}{*}{ Tooth } & \multicolumn{2}{c}{ wo/M } & group & \multicolumn{2}{c}{ w/M } & group \\
mean & (S.D.) & mean & (S.D.) \\
\hline $\mathrm{I}_{1}$ & 15.0 & $(25.7)$ & 1.8 & $(5.2)$ \\
$\mathrm{I}_{2}$ & 12.6 & $(22.1)$ & 3.3 & $(5.4)$ \\
$\mathrm{C}$ & 19.7 & $(28.6)$ & 8.4 & $(10.1)$ \\
$\mathrm{P}_{1}$ & 23.1 & $(25.0)$ & 25.5 & $(39.6)$ \\
$\mathrm{P}_{2}$ & 30.5 & $(31.8)$ & 20.1 & $(22.6)$ \\
$\mathrm{M}_{1}$ & 130.4 & $(67.0)$ & 74.1 & $(63.1)$ \\
$\mathrm{M}_{2}$ & 211.8 & $(111.3)$ & 199.7 & $(99.5)$ \\
$\mathrm{M}_{3}$ & - & $(-)$ & 93.4 & $(63.1)$ \\
\hline
\end{tabular}

左右各片側歯列の咬合力および歯列全体における咬合力 （総咬合力）を求めた。また咬合力の下顎歯列における 分布を明らかにする目的で，下顎各歯における咬合力が 総咬合力に占める比を求め，これを各㐘における咬合力 比とした。さらに，左右側歯列に打ける咬合力の配分の 均等さを表す指標として, 左右各側歯列における咬合力 の差が，総咬合力に占める比を求めた (非対称性指数).

下顎各歯における咬合力ならびに咬合力比は, 各被験 者の左右各片側歯列，あわせて 84 側を下顎第 3 大臼歯に 咬合接触を認める群 (with $\mathrm{M}_{3}$ contacts群, 以下 $w / \mathrm{M}_{3}$ 群 と略記）と認めない群（without $\mathbf{M}_{3}$ contacts群，以下 wo/ $\mathbf{M}_{3}$ 群と略記）に分類し, それぞれの群について, 個 別に検討した。

\section{III. 結 果}

口腔内診査の結果，本研究に用いた被験者の一人平均 処置歯数，未処置歯数ならびに喪失歯数は，それぞれ73 歯，0.7歯拉よび0.1歯であった。

記録された総咬合力は205～1963Nに分布し，平均 $879 \pm 388 \mathrm{~N}$ であった。咬合力作用面積は $3.8 \sim 36.2 \mathrm{~mm}^{2}$ に 分布し, 平均 $16.9 \pm 8.4 \mathrm{~mm}^{2}$ であった。

現在歯の診査結果ならびにチェックバイトより，全被 験者の左右側別下顎歯列 84 側は, wo/ $\mathrm{M}_{3}$ 群65側および w/ $\mathbf{M}_{3}$ 群19側に分類された. $\mathbf{w o} / \mathbf{M}_{3}$ 群およびw/ $\mathbf{M}_{3}$ 群の片 側歯列における咬合力は，それぞれ平均 $443.1 \pm 207.1 \mathrm{~N}$

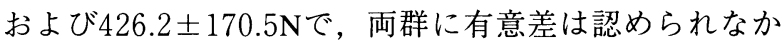
った。

各歯における咬合力は前歯，小臼歯，大兒歯の順に増 大した. $\mathrm{wo} / \mathrm{M}_{3}$ 群と $\mathrm{w} / \mathrm{M}_{3}$ 群を比較したところ, w/ $/ \mathrm{M}_{3}$ 群 の各歯の咬合力は前歯および第 1 大白歯で有意に小さか つた（p<.01）[表 1].

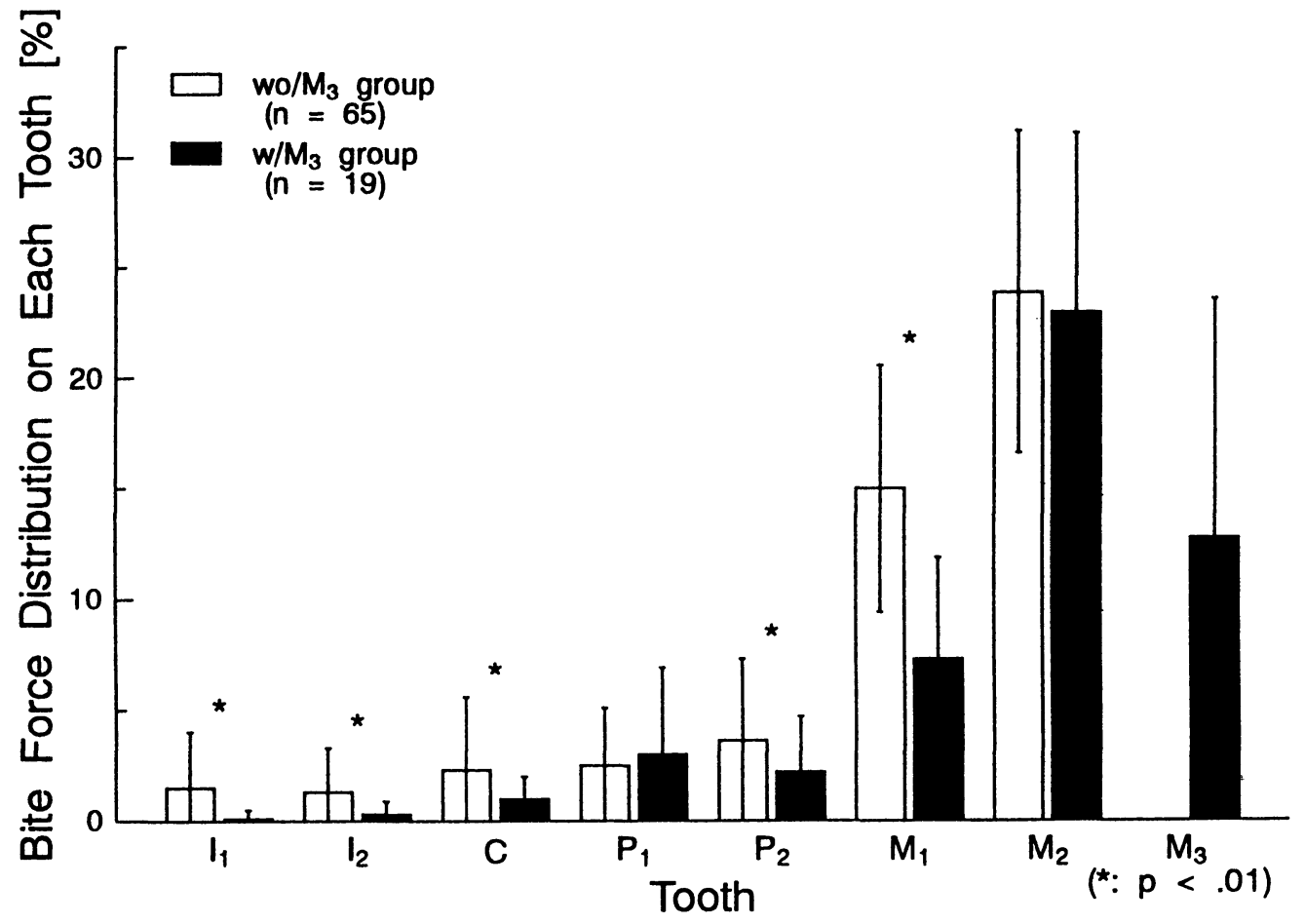

図各歯における咬合力比

Figure Bite force distribution on each tooth 
表 2 左右側歯列における咬合力の対称性

Table 2 Asymmetry Index for bite force

\begin{tabular}{|c|c|c|c|}
\hline \multirow{2}{*}{ group } & \multirow{2}{*}{$\mathrm{n}$} & \multicolumn{2}{|c|}{ Asymmetry index } \\
\hline & & mean & (S.D.) \\
\hline $\mathrm{wo} / \mathrm{M}_{3}-\mathrm{wo} / \mathrm{M}_{3}$ & 30 & 10.3 & (7.1) \\
\hline $\mathrm{w} / \mathrm{M}_{3}-\mathrm{wo} / \mathrm{M}_{3}$ & 5 & 8.1 & (6.2) \\
\hline $\mathrm{w} / \mathrm{M}_{3}-\mathrm{w} / \mathrm{M}_{3}$ & 7 & 6.2 & $(4.0)$ \\
\hline all subjects & 42 & 9.3 & (6.7) \\
\hline
\end{tabular}

下顎各歯における咬合力比は, $w o / M_{3}$ 群では第 2 大臼 歯で最大值を示し, 第 1 大臼歯, 第 2 小臼歯の順に減少, 切歯部で最小であった。 $\mathrm{w} / \mathrm{M}_{3}$ 群では同じく第 2 大臼歯 で最大值を示し, 第 3 大臼歯, 第 1 大臼歯の順に減少し, 切歯部で最小であった. 各歯の咬合力比を両群で比較し たところ, $\mathrm{w} / \mathrm{M}_{3}$ 群の切歯, 犬歯抢よび第 2 小臼歯，第 1 大曰歯の咬合力比は, $w o / \mathrm{M}_{3}$ 群と比較して有意に小さ かった $(\mathrm{p}<.01)$ [図]. 前歯部，小臼歯部，大白歯部の 咬合力比を両群で比較したところ, w/ $/ \mathrm{M}_{3}$ 群ではwo/ $\mathbf{M}_{3}$ 群と比較して, 前歯部の咬合力比が有意に小さく $(\mathrm{p}<.01)$, 大臼歯部の咬合力比が有意に大きかった $(\mathrm{p}<.05)$.

咬合力の左右的非対称性指数は，42名の被験者で $9.3 \pm 6.7 \%$ でった，左右側歯列ともに第 3 大白歯に咬 合接触を有さない被験者 30 名 (wo/ $\mathrm{M}_{3}$-wo/ $\mathrm{M}_{3}$ 群), いず れか片側の第 3 大臼歯に咬合接触を有する被験者 5 名 (w/ $\mathbf{M}_{3}-\mathbf{w o} / \mathrm{M}_{3}$ 群) ならびに両側第 3 大臼歯に咬合接触 を有する被験者 7 名 (w/M $/ \mathrm{M}_{3}-\mathrm{w} / \mathrm{M}_{3}$ 群) の 3 群で, それぞ れ咬合力の左右的非対称性歯数を求めたところ, w/ $/ \mathrm{M}_{3}$ w/M 3 群にて最小であり, ついでw/ $/ M_{3}-w o / M_{3}$ 群, 最大 がwo/M $\mathbf{M}_{3}-\mathrm{wo} / \mathrm{M}_{3}$ 群であった [表 2].

\section{IV. 考察}

\section{1. 測定方法}

1) 被験者

本研究に用いた被験者の現在歯の状況は，平成 5 年歯

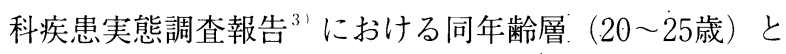
比較して, 一人平均未処置歯数がやや小さいほかは, 一 人平均処置蒾数, 丧失菌数がほぼ一致し, その選択には 偏りのないことが示唆された。したがって, 本研究で得 られた咬合力分布を，正常者の平均像と考えてよいと思 われる。

2 ）感圧フィルム

フィルムの厚さが咬合力分布の測定結果に及ぼす影響 への懸念が指摘されている+6!．歯列間に均一な厚さの
材料を介在させる測定方法では，仮に顎関節が蝶番軸と して機能すれば，これに近い後方歯部ほど厚さの影響が 大きく現れ，その結果咬合力比が過大となる可能性があ る.

著者らは同一組成の感圧材料をより薄いフィルムに塗 布した, 厚さ56 $\mu \mathrm{m}$ の試作品を富士写真フィルム株式会 社より入手し, 若干名の被験者にもちいて，咬合力の測 定を試みた。その結果，現行の $97 \mu \mathrm{m}$ フィルムと薄型の 試作品間で, 記録された咬合力分布にほとんど差が認め られなかった。

フィルム厚さの影響はいまだ明らかではないが，機能 力による歯や下顎頭の変位量, 顎骨の変形量などとの関 係に扔いて考察する必要があろう。

3 ) 測定条件

著者らはこれまで，感圧フィルムを応用した咬合力測 定法に関する検討を行うとともに，この測定法を正常有 歯顎者に用いて歯列に作用する咬合力の測定を行ってき た ${ }^{1,2,7-11)}$. 同一の被験者にて，中等度から最大に至 る範囲で咬みしめ強さを変え, 咬合力測定を重ねた結果, 各歯の咬合力比はほぼ一定で, その標準偏差は総咬合力 の $3 \%$ 未満であった2!。これょり，中等度以上の咬みし めを測定条件として咬合力を記録することにより, 被験 者毎に固有の咬合力分布を，再現性よく得ることができ ると判明した。

そこで本研究では「できるだけ強く」咬むよう指示す るのみとした。また，咬合力分布の測定における再現性 の高さを考慮し, 本研究では各被験者の測定回数を 1 回 のみとした。

\section{2. 前後的咬合力分布}

本研究の結果, 中心咬合位付近で最大咬みしめを行っ た際の咬合力分布に関して, 以下の知見が得られた。

各歯における咬合力は，第 3 大臼歯に咬合接触を有す る歯列では，第 2 大臼歯にてもっとも大きく，ついで第 3 大臼歯, 第 1 大目歯, 第 1 小曰歯, 第 2 小曰歯, 犬歯, 側切歯の順に咬合力が減少し, 中切歯で最小であった. また第 3 大白歯に咬合接触を有さない歯列では, 第 2 大 田歯で最大であり, ついで第 1 大臼歯, 第 2 小臼歯, 第 1 小曰歯, 犬歯, 中切歯の順に咬合力が減少し, 側切歯 で最小值を示した。第 3 大臼菌の咬合接触の有無により 分類した 2 群間で咬合力分布を比較したところ，大兒歯 部の咬合力は第 3 大臼歯の咬合接触を有する群で有意 $(\mathrm{p}<.05)$ に大きく，前歯部の咬合力比は第 3 大臼歯の 咬合接触を有さない群で有意 $(\mathrm{p}<.01)$ に大きかった. 小臼歯部の咬合力比に有意差は認められなかった。

両群ともに咬合力比が最大である第 2 大臼歯と, 最小 
である中切歯もしくは側切歯で, 咬合力比の比を求めた ところ，第 3 大臼歯に咬合接触を有さない群では約18倍, 有する群では230倍に及んだ。これらの結果は, 咬合力 分布の前後的勾配が両群で異なり，第 3 大臼歯に咬合接 触を有する群においてより急峻であることを示すもので ある。

このような咬合力の前後的分布を理解する目的で，各 歯における咬合力を規定する 3 要素 ${ }^{12)}$ とされる，歯周組 織の咬合力負担能力，槓桿作用ならびに咀嚼筋活動につ いて，考察する。

歯周組織の負担能力に関して，各歯別個に検討した結 果が報告されている ${ }^{13)}$ 。この報告では，対顎の負担能力 を高めるために数歯を連結し，これと被験歯の間に咬合 力計を介在させて, 咬みしめ強さの増大によって被験者 が被験歯に疼痛を自覚する時点の咬合力を記録してい る.記録された各歯の咬合力（高見沢の造語で個歯咬合 力）は，その上限が扔そらくは歯周組織の痛覚間值によ って規定されており，これにより咬合力負担能力を適切 に評価し得ると考えられる。報告によれば，下顎各歯の 個歯咬合力は第 1 大臼歯で最大 $(74.49 \mathrm{~kg})$ であり，つ いで第 2 大白歯 $(70.44 \mathrm{~kg})$ ，第 2 小臼歯 $(55.36 \mathrm{~kg})$ ，第 1 小臼歯 $(44.32 \mathrm{~kg})$, 犬歯 $(31.36 \mathrm{~kg})$, 中切歯 $(20.15 \mathrm{~kg})$ の順に減少し，側切歯（19.65kg）で最小である．歯周 組織の咬合力負担能力は歯の植立方向，歯根の形態や表 面積などを反映すると予想される，下顎歯の歯根表面積 は第 1 大画歯で最大, 中切歯で最小 ${ }^{14)}$ であり, 咬合力負 担能力との関係が示唆されている.しかしながら各歯の 負担能力は，最大である第 1 大臼歯と最小值である側切 歯で，その比が約3.8倍にすぎない.

本研究にて得られた咬合力の前後的分布は，その前後 的勾配が歯周組織の負担能力の前後比と比較して明らか に急峻であり，咬合力分布が各歯の負担能力を直接に反 映してはいないことを示す結果と考えられる.

咬合力の規定に関わる第 2 の要素，槓桿作用とは，顎 口腔系を梃子とみなすものである．力点である閉口筋付 着部に働く筋収縮力が同一の場合，作用点である歯にお いて発揮される咬合力は，その歯が支点である顎関節に 近い順に大きい．頭部X線規格写真をもとにその影響を 試算したGosen ${ }^{15)}$ によれば，第 2 大臼歯の咬合力を $100 \%$ とした場合，第 1 大臼歯では $86.22 \%$ ，第 2 小臼歯で $77.75 \%$ と漸次減少し, 中切歯にて最小の $62.25 \%$ となる。 第 2 大臼歯と中切歯では，その比が1.6倍である。した がって, 本研究の咬合力分布が単に槓桿作用の結果でな いことは明らかである。

一方, 三次元有限要素法を用いた数理モデルを用いて,
各種咬みしめを行った際の咬合応力とその分布を検討し た結果が報告されている ${ }^{16,17)}$.

相馬ら ${ }^{16)}$ は，下顎骨，下顎歯列，食塊よりなるモデル を設定し，咬筋，側頭筋，内，外側翼突筋の筋力を与え て，食塊に作用する応力を求めた。下顎歯列弓を模した 歯列弓モデルは放物線状形で，咬合面に相当する上端面 が平坦とされた。下顎骨は蒾槽骨を含めた形態に，また 食塊を想定したバイトブロックモデルは馬蹄形板状で, 歯列弓モデルと固着するものとして設定された。このモ デルから得られた咬みしめ時の咬合力は，歯列上で後方 から前方にかけて減少する左右対称な分布を示した。 各 部の圧縮応力は, 放物線状形の標準的歯列弓形態では, 前歯最前方部を $100 \%$ とした場合，小臼歯部煩側で127\%， 大臼歯最後方部煩側では175\%であった。歯列弓の上端 面にスピー湾曲を模した前後的湾曲を付与したところ， 圧縮応力はそれぞれ133\%および189\%に変化した。また モンソン湾曲を模した攧舌的湾曲を付与した場合，それ ぞれ142\%および197\%へと増大した。このように歯列弓 形態が咬合力の前後的勾配に影響を及ぼすことが判明し た。しかしながらこのモデルにより得られた咬合力分布 の前後的勾配は，本研究の結果と比較して，きわめて緩 やかである。

Korioth とHannam ${ }^{177}$ は完全な歯列を有する新鮮屍体の 下顎骨をX線CTにて撮像し，これを 3 次元構築してモデ ルを作成した。モデルの下顎骨は皮質骨，海綿骨からな り，顎関節は下顎頭，関節円板と側頭骨下顎窩の線維軟 骨を複合した第 1 層と側頭骨下顎窩の皮質骨を模した第 2 層の 2 層からなるキャップとして表現された。歯は単 根もしくは 2 根でエナメル質と象牙質よりなり, 歯周組 織は歯根膜掞よび歯槽硬線によって構成される。このモ デルに左右側の咬筇浅部および深部, 側頭筋前, 中, 後 部，内側翼突筋，外側翼突筋上頭および下頭，顎二腹筋 前腹に由来する 9 対の筋収縮力を与えた。その結果，咬 合力は前後的には第 3 大臼歯で最大であり, 第 2 大臼歯, 第 1 大臼歯，小臼歯の順に減少し，犬歯で再び増大，切 歯では0であった，左右的にはほぼ対称的な分布を示し た。図より読みとるに，第 3 大臼歯の咬合力を $100 \%$ と すると，第 2 大臼歯の咬合力は $50 \%$ 弱，第 1 大臼歯は 20 ～30\%，小且歯では数\%である．咬合力分布の前後的勾 配を本研究の結果と比較すると，第 3 大臼歯や犬歯など 異なる箇所は多いが，その傾向はおおむ打類似した。

これら 2 つのモデルでは，咬合力の前後的勾配におい て小さからざる差があるものの，咬合力分布の前後的な 傾向はいずれも本研究の測定結果と近似した。前者モデ ルにより, 歯列弓の位置, 形態, 咬合面の矢状もしくは 
側方湾曲などが，咬合力分布に影響を及ぼすことが示さ れたことから，モデルと本研究の結果の間における咬合 力分布の相違が, モデルと生体の形態的, 構造的相違に 起因することは容易に推察される.

咬合力を規定する第 3 の要素である咀嚼筋活動の影響 は明らかではない．後者モデルでは左右 9 対の筋収縮力 を入力し, 前者モデルと比較して, はるかに生体に近似 した咬合力分布を得た。一方，三次元咬合力測定に基づ く咀嚼筋活動の検討から, 被験者間で咀嚼筋の協調様式 に相違が認められている ${ }^{18)}$. 後者モデルにおいて入力さ れた顎顔面形態と筋活動は，それぞれ別の被験者より得 られた結果である。モデルより得られた咬合力分布が, 本研究の生体における測定結果と相違する原因の一つと して, 咀嚼筋活動の相違が推察される。

以上より，生体における咬合力の前後的分布は，咬み しめ時に生じる歯の変位や骨の弾性変形, 槓桿作用, 咀 嚼筋活動などが複合的に影響し，これらにより規定され ることが示唆された．また，第 3 大臼歯の咬合接触の有 無による前歯部や第 1 大臼歯の咬合力比の有意差は, 両 群の被験者における顎口腔系の形態や構造, 咬合位, 咀 嚼筋活動様式など統合作用の相違によってもたらされた 結果であると推察される.

\section{3. 咬合力分布の左右的対称性}

咬合力の左右的分布に関して, 本研究では左右各側歯 列に作用した咬合力の差が総咬合力に占める比を用いて 分析を行った。 その結果, 本研究の被験者における左右 的対称性は平均 $9.3 \pm 6.7 \%$ あったた。れは，正常な機 能を営む顎口腔系が，その力学的特性として，咬合力が 左右的に均等に分布する特徴を有することを示すもので ある。

これまでも T-Scan法やPhotocclusion法を用いた検討か ら，正常者の咬合力分布の左右対称性が指摘されていた $\left.{ }^{19}, 20\right)$ が，咬合力測定法の定量性が疑問視されることから， その根拠は脆弱である.

佐藤ら ${ }^{21}$ は, 正常者 4 名の非対称性指数を $8 \%$ 未満と 報告したが，これは佐藤らの用いた被験者が，いずれも きわめて健全な歯列を有することによるものであろう。

また，第 3 大臼歯に咬合接触のない群，片側のみに咬 合接触のある群，両側に接触のある群を比較すると，そ の順に左右的対称性が高くなることから，咬合接触を有 する臼歯数の増大に伴う咬合力分布の左右的均等化が示 唆された.

\section{4.咬合力を指標とした咬合診查}

咬合力分布の記録は簡便でありながら再現性が高く, 記録された咬合力分布は各被験者の顎顔面口腔の形態,
機能を反映した，固有のものである．また測定に用いる 咬みしめは基本的な口腔機能のひとつであることから， 記録した咬合力分布とその正常像との比較は，口腔機能 の良否の診断に有用と推察される.

また本研究にて得られた咬合力分布は，咬合診断に際 して参照されるべき正常像であると考えられる.

測定に用いる感圧フィルムの厚さの影響に関しては, 咬合力測定のために両顎歯列間に何らかの材料を介在さ せることは，いわば必然であり，同一方法により記録さ れた結果間の比較は, 診断方法として臨床上妥当と考え られる。

感圧フィルムを両顎歯列間に介在させることにより， 空口時と比較して, 最大咬みしめ時の咬筋活動量は増大 する. 感圧フイルムの介在により，咬合接触の均等化が 生じた結果と推察される. 介在させる材料の厚さ, 物理 的性質の検討は，このような生体機能との関わりに基つ” いて行われるべきと考えられる.

\section{V. 結 論}

歯列に扮ける咬合力分布の正常像を明らかにする目的 で, 顎口腔系に機能異常とその既往を認めない有歯顎者 42 名より, 感圧フィルムを用いて最大咬みしめ時の咬合 力を記録し，以下の結果を得た。

1.下顎歯の咬合力比は㧍扮むね後方歯から前方歯にか けて減少し，第 2 大臼歯にて最大であった，前歯か ら第 2 大曰歯にかける咬合力分布の前後的勾配は, 第 3 大臼歯に咬合接触を有する群で，より急峻であ った。

2.咬合力は左右側歯列にほほ均等に配分された。咬合 接触を有する第 3 大臼歯数が多いほど，咬合力の左 右的対称性は高かった。

3. 咬合力分布のこのような特徵は, 歯や顎関節の変位, 顎骨の变形, 歯周組織の咬合力負担能力, 槓桿作用 のほか, 筋活動の影響の統合の結果と推察された。

4. 本研究において得られた咬合力分布は，咬合力を指 標とした咬合診査において参照すべき正常像と考え られた。

\section{文献}

1）服部佳功，奥川博司，渡辺誠：Dental Prescaleを用 いた歯列における咬合力測定，補綴誌，38： 835-841, 1994.

2 ）佐藤智昭，服部佳功，渡辺誠：咬みしめ強さと歯列 
における咬合力分布，顎機能誌，投稿中.

3 ）厚生省健康政策局歯科衛生課編：平成 5 年歯科疾患 実態調査報告，129，口腔保健協会，東京，1995.

4 ）久恒泰宏, 增木英郎, 松本貴子ほか：「デンタルプ レスケール」を用いた咬合接触圧の測定一基礎的検 討一，補緅誌，37·89回特別号：109，1993.

5 ）鈴木哲也, 熊谷宏, 吉富信幸ほか：咬合圧測定シス テムの臨床応用に関する研究，口病誌，61： 437-445, 1994.

6 ）鈴木哲也, 渡邊竜登美, 吉富信幸ほか：感圧シート を用いた新しい咬合圧測定システムの有用性, 補緅 誌, $38 ： 966-973,1994$.

7 ）渡辺誠, 服部佳功：Dental Prescale 50 を用いた咬合 診査とその臨床応用，歯界展望，84：109-126, 1994.

8 ）服部佳功, 渡辺誠：咬合力測定に関する最近の進歩, 歯界展望，85：657-668，1995.

9 ) 渡辺誠, 服部佳功, 佐藤智昭：あたらしい咬合力測 定システムによる咬合診断とその臨床的意義〜 "Dental Prescale 50" と "Occluzer" によるシステム〜， 歯科技工, $23: 650-660,1995$.

10）渡辺誠, 服部佳功, 菊池雅彦ほか："Dental Prescale 50" の臨床応用，歯科技工, $23: 661-676,1995$.

11) Watanabe, M., Hattori, Y. and Satoh, C.: Bite force distribution on the dental arch in normal dentitions, edited by Morimoto, T., Matsuya, T. and Takada, K., Brain and oral functions, 399-403, Elsevier Science B.V., the Netherlands, 1995.

12）河村洋二郎：口腔生理学, 212-226, 永末書店, 京 都, 1973.

13）高見沢忠：健常永久歯の相対咬合力および個歯咬合 力に関する研究，補綴誌，9:217-236, 1965.

14) Jepsen, A.: Root surface measurement and a method for X-ray determination of root surface area, Acta Odontol Scand, 21: 35-46, 1963.

15) Gosen, A.J.: Mandibular leverage and occlusion, J Prosthet Dent, 31: 369-376, 1974.

16）相馬邦道，石田哲也，三浦不二夫：各種形態の歯列 弓上における咬合応力分布, 日矯歯誌, 50 ： 224-240, 1991.

17) Korioth, T.W.P. and Hannam, A.G.: Mandibular forces during simulated tooth clenching, J Orofacial Pain, 8: 178-189, 1993.

18）服部佳功，菊池雅彦，佐々木啓一ほか：三次元咬合 力と咀嚼筋活動量, 顎機能, $9: 33-38,1991$.

19）鍋島史一, 田中昌博, 河野亘ほか：T-Scanシステム から見た咬頭嵌合位での咬合接触バランス，補綴誌， $34: 340-348,1990$.

20) Gianniri, A.I., Melsen, B., Nielsen, L. et al.: Occlusal contacts in maximum intercuspation and craniomandibular dysfunction in 16-to 17-year-old adolescents, $\mathrm{J}$ oral Rehabil, 18: 49-59, 1991. 